\title{
The fate of heavy metals during combustion and gasification of contaminated biomass-A brief review
}

\author{
Ange Nzihou ${ }^{\mathrm{a}, *}$, Brian Stanmore ${ }^{\mathrm{b}}$ \\ a Université de Toulouse, Mines Albi, CNRS, Centre RAPSODEE, Campus Jarlard, F-81013 Albi cedex 09, France \\ ${ }^{\mathrm{b}}$ Formerly of the University of Queensland, Brisbane, QLD 4072, Australia
}

\section{H I G H L I G H T S}

- A review on metal behaviour during the thermal treatment of contamined biomass.

- Wide range of biomass waste reported.

- Distribution of metals in the ash, and in the sub-micron particles discussed.

\section{A B S T R A C T}

The literature on the presence of heavy metals in contaminated wastes is reviewed. Various categories of materials produced from domestic and industrial activities are included, but municipal solid waste, which is a more complex material, is excluded. This review considers among the most abundant the following materials - wood waste including demolition wood, phytoremediation scavengers and chromated copper arsenate (CCA) timber, sludges including de-inking sludge and sewage sludge, chicken litter and spent pot liner. The partitioning of the metals in the ashes after combustion or gasification follows conventional behaviour, with most metals retained, and higher concentrations in the finer sizes due to vaporisation and recondensation. The alkali metals have been shown to catalyse the biomass conversion, particularly lithium and potassium, although other metals are active to a lesser extent. The most prevalent in biomass is potassium, which is not only inherently active, but volatilises to become finely distributed throughout the char mass. Because the metals are predominantly found in the ash, the effectiveness of their removal depends on the efficiency of the collection of particulates. The potential for disposal into soil depends on the initial concentration in the feed material.

Keywords:

Contaminated biomass

Heavy metals

Partitioning

Combustion

Gasification

\section{Contents}

1. Introduction

2. Results and discussion

2.1. Wood waste

2.1.1. - Demolition and other contaminated timber

2.1.2. Phytoremediation scavengers (phytoextractors).

2.1.3. Chromated copper arsenate (CCA) wood...

2.2. Sewage and Paper sludge....

2.2.1. - Sewage sludge.

2.2.2. Paper sludges

2.3. Chicken litter.

2.4. Spent pot liner...

2.5. Role of metal alkali .

3. Discussion

4. Conclusions

References .

\footnotetext{
* Corresponding author. Tel.: +33 563493222; fax: +33 563493099.

E-mail address: ange.nzihou@mines-albi.fr (A. Nzihou).
} 


\section{Introduction}

Due to the various applications of some biomass materials, metals may become concentrated after use into the residual wastes, which then require responsible disposal. Examples of contaminated biomass considered in this review are demolition wood, phytoremediation scavengers, CCA timber, paper recycling wastes such as de-inking sludge, spent pot liner, chicken litter and sewage sludge. These materials are increasingly being subjected to thermal treatment such as combustion and gasification.

The metals under consideration are those regarded as harmful [1], namely As, Cd, CrVI $, \mathrm{Cu}, \mathrm{Hg}, \mathrm{Mn}, \mathrm{Ni}, \mathrm{Pb}, \mathrm{Se}, \mathrm{Tl}$ and $\mathrm{V}$. These can be incorporated into biomass at trace concentrations during normal growth, but may be present at elevated levels in some applications. Fig. 1 from Obernberger et al. [2] represents the formation of ash from biomass during a combustion process. As depicted there, any more volatile heavy metals such as lead, zinc and cadmium (and also selenium) would tend to vaporise and recondense on fine particles. The remaining less volatile ones would mostly follow a path into the char and then into the bottom ash.

Although contaminated biomass will be considered here, there is a problem with burning even virgin wood and straw, due to the amount of cadmium in the fly ashes. It is phytotoxic and may lead to functional kidney disorder and bone damage, along with other detrimental effects [3]. In Denmark the application of such ashes to soil is banned because this is predicted to lead to rising soil concentrations of cadmium, which will sooner or later exceed acceptable levels [4]. The problem is addressed by Pedersen [5], who reports concentrations of $2-10 \mathrm{mg} \mathrm{kg}^{-1}$ of $\mathrm{Cd}$ in wood ash, compared to about $1 \mathrm{mg} \mathrm{kg}^{-1}$ in virgin wood, see Table 1 .

Although the concentrations of heavy metals in biomass are low, the total mineral matter is also low. Accordingly, when the metals are concentrated into a combustion ash, they are present in relatively high concentrations on a mass basis. For example, the ash content of wood is typically one tenth to one twentieth of that of a co-fired coal, but a comparison [6] of some fly ashes and bottom ashes from coal firing show similar concentrations of $\mathrm{As}, \mathrm{Cd}, \mathrm{Cr}, \mathrm{Cu}$, $\mathrm{Pb}$ and $\mathrm{Hg}$ to the equivalent wood ashes. However, the total flux of heavy metals emitted from a boiler favours biomass because of the small quantities involved. Compared to wood, the concentrations of heavy metals are generally less in agricultural byproducts like the shells of nuts.

Table 1 lists some heavy metal contents of the materials under consideration, with clean wood and straw included for comparison. As these compositions will be extremely variable depending on the source, the author of the data is included. Where a figure is in brackets, the value has been taken from another author. Preference is given to data which include many samples taken from a survey, rather than for a particular sample studied. All the contaminated materials show elevated levels of heavy metals, with demolition timber and recovered solid fuel the worst.

The data for demolition timber are mean values from a survey in the USA, but similar data from Scandinavia [7] show that more care is taken in selecting fuel in that country. The figures for biomass phytoremediation are a composite from a study examining the performance of Amaranthus dubius at three heavily contaminated sites [8]. In each case, the maximum level measured in the plant across the three sites is reported. The figures for sewage sludge are the mean of samples from across Europe [9].

As background information, the behaviour of both the biomass and the metals under thermal treatment will be considered for the better-understood cases of conventional (uncontaminated) fuels. The case of contaminated fuel can then be considered in relation to these documented processes.

In each case of thermal treatment, the biomass undergoes drying, and then pyrolysis as a preliminary step. Organic structures disintegrate to give tars, gases and char, and the more volatile inorganics such as alkali metals and chlorine are evolved. The fate of heavy metals is determined later on as higher temperatures are attained.

In most combustion systems, there are three ash streams emerging, namely the bottom ash, the flyash collected in the gas cleaning system, and the fugitive ash which escapes the gas cleaning system and is lost up the stack. There is enrichment of the more volatile elements into the flyash, especially in the very fine ash particles. However, an examination of the flyash collected from the different stages of a 3 stage ESP processing the fluegas from a boiler cofiring coal and wood showed that concentrations of the refractory metals $\mathrm{Mn}, \mathrm{Fe}$, and $\mathrm{Cu}$ were almost the same across the stages, while $\mathrm{Pb}$ and $\mathrm{Zn}$ were below the limit of detection [10]. Some data on the distribution of ash during combustion can be seen in Table 2 where a number of measured results are assembled. The result from Narodoslawsky and Obernberger [11] are for a mixture of bark and wood chips burned in a $4 \mathrm{MW}_{\mathrm{t}}$ moving grate furnace. The system was fitted with both a cyclone and a fabric filter, and the stack was sampled for fugitive particulates. The furnace studied by Li et al. was a $12 \mathrm{MW}_{\mathrm{t}} \mathrm{CFB}$ burning a mixture of cotton stalk, rice husk and bark. The furnace studied by Li et al. was a $32 \mathrm{MW}_{\mathrm{t}}$ BFB firing $50 \%$ forest residues and $50 \%$ peat. The figures from Narodoslawsky are presented as a percentage of the metal in the feed, while the others are the mass concentrations in the ash from each stream.

The ash partitioned into the bottom ash, the cyclone fly-ash (where present), the filter fly-ash and the remainder emerged with the flue gas. In the case of the smaller system studied by Narodoslawsky, $64.5 \%$ of the ash reported to the bottom stream, $28.5 \%$ to the cyclone, and only $5.4 \%$ was caught in the fabric filter. It was found that only $1.6 \%$ escaped up the stack. In contrast, with a bubbling fluidised bed and a finely divided fuel, $90 \%$ was recovered in the ESP [12].

Most of the metals represented are found either in the bottom or cyclone ash, and less than 7\% escape into the atmosphere [11]. Even the volatile metals like cadmium and lead are present at $10-12 \%$ in the fluegas, and mercury $21 \%$. In systems high in chlorine content, such as RDF incineration, the metals will tend to form chlorides which have a much higher vapour pressure than the usual oxides.

The partitioning of the metals is conventionally quantified by an enrichment factor RE, which is the ratio of the concentration of element in an ash from a combustor to its effective concentration in the ash content of the original fuel. The metals are then allocated into classes, with Class I being the least volatile and Class III the most. The intermediate Class II is further subdivided into a, b, and c. Class I non-volatile metals such as $\mathrm{Ca}, \mathrm{Fe}, \mathrm{Cu}, \mathrm{Cr}$ and Ni with an $\mathrm{RE}$ of about 1 will not vaporise readily and will exit principally in equal concentrations in the bottom ash and the flyash. Cobalt, copper and nickel (IIc) typically exhibit an RE of $2-4$. Class Ila elements like Cd and $\mathrm{Sb}(\mathrm{RE}>4)$ are somewhat volatile and any vaporised material will have recondensed on the surface of fine ash. The Class III metals mercury, boron and selenium tend to escape mostly as vapour and will be little represented in most ashes. The value of RE rises sharply as the particle size of the flyash decreases, because of the higher area per unit mass.

Only mercury and selenium, and to a lesser extent arsenic will escape a combustion system as vapour. Mercury is especially volatile, and can be emitted almost totally as vapour, in the form of the element $\mathrm{Hg}^{\circ}$ and an oxidised form $\mathrm{HgCl}_{2}$. Oxidised mercury represented between 80 and $97 \%$ of the $\mathrm{Hg}$ emissions entering the air pollution control systems of MSW incinerators in Taiwan [13]. The percentage was lower after the APC systems (75-80\%), indicating that oxidised $\mathrm{Hg}$ is easier to collect.

All the other elements are found to be present overwhelmingly on the ash (e.g. Pavageau et al. [14], Lind et al. [15], Latva-Somppi et al. [16]. As a result, the efficiency of the removal of metals is 


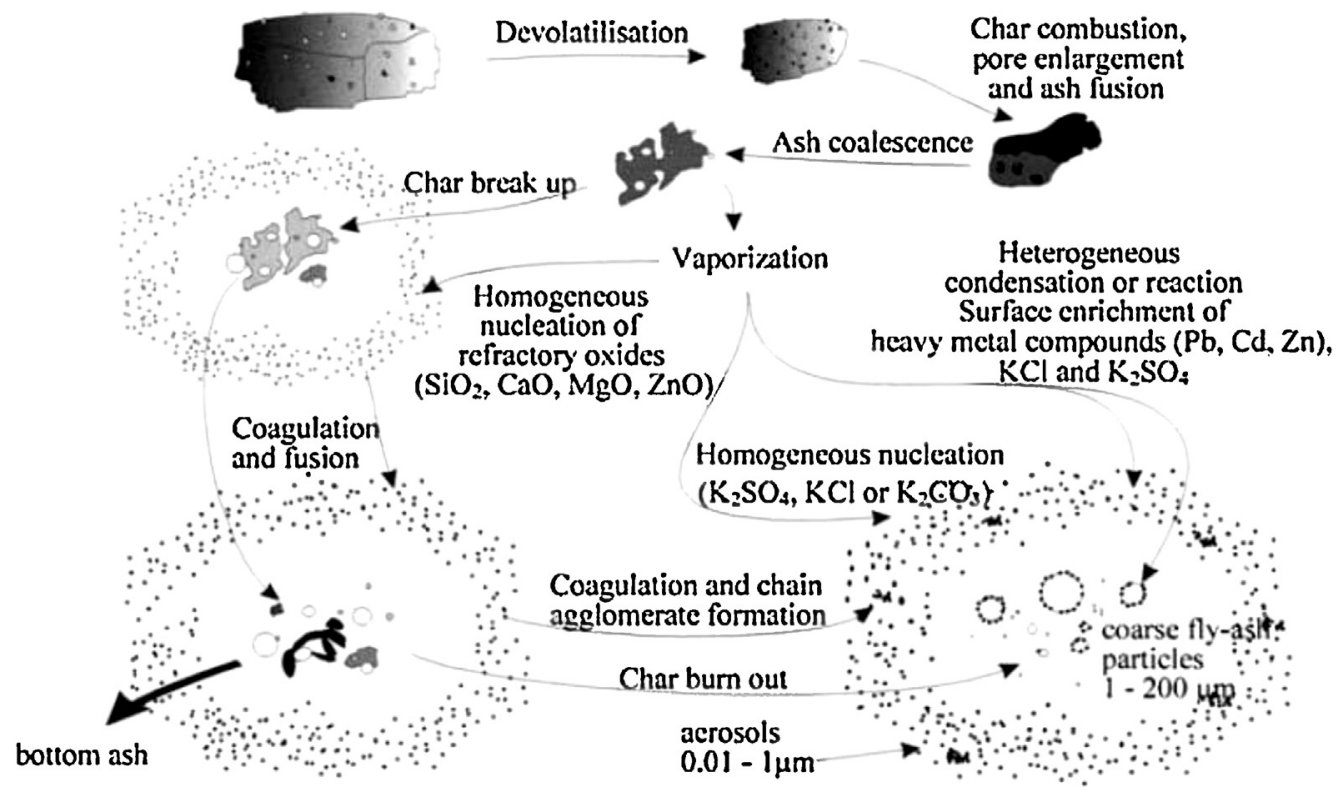

Fig. 1. Schematic of ash formation from biomass during combustion [2].

Table 1

Some levels of metal content in biomass.

\begin{tabular}{|c|c|c|c|c|c|c|c|c|c|}
\hline \multirow{2}{*}{$\begin{array}{l}\text { Biomass } \\
\text { Author }\end{array}$} & \multirow{2}{*}{$\begin{array}{l}\text { Wheat Strawa } \\
\text { [6] }\end{array}$} & \multirow{2}{*}{$\begin{array}{l}\text { Beech Wood } \\
\text { [6] }\end{array}$} & \multirow{2}{*}{$\begin{array}{l}\text { Demol Timber } \\
\text { [31] }\end{array}$} & \multirow{2}{*}{$\begin{array}{l}\text { Phyto Remed } \\
\text { [8] }\end{array}$} & \multirow{2}{*}{$\begin{array}{l}\text { Sewage Sludge } \\
\text { [9] }\end{array}$} & \multirow{2}{*}{$\begin{array}{l}\text { Chicken Litter } \\
\text { [67] }\end{array}$} & \multicolumn{2}{|c|}{ Paper Sludge } & \multirow{2}{*}{$\begin{array}{l}\text { Recov Fuel } \\
{[18]}\end{array}$} \\
\hline & & & & & & & [16] & [63] & \\
\hline \multicolumn{10}{|c|}{ Metal content ( $\mathrm{mg} \mathrm{kg}^{-1}$ dry basis) } \\
\hline As & 0.18 & 3.5 & 550 & 22 & $(10)$ & - & 8 & - & 37 \\
\hline Cd & 0.2 & 1.0 & 8 & - & 38 & - & $<0.4$ & 350 & 24 \\
\hline Co & 3.0 & - & - & - & - & - & $9-12$ & - & 67 \\
\hline $\mathrm{Cr}$ & 25 & 2.5 & 1060 & 107 & 91 & 112 & 110 & 100 & 1020 \\
\hline $\mathrm{Cu}$ & 0.06 & 43 & 1080 & 70 & 330 & 71 & 310 & 450 & 2800 \\
\hline $\mathrm{Hg}$ & 6 & 0.12 & 10 & 8 & 2.7 & - & 1000 & - & - \\
\hline Mn & - & (73) & (2500) & - & 950 & 596 & 55 & - & 1650 \\
\hline $\mathrm{Ni}$ & & - & - & 27 & 39 & $<10$ & - & 480 & 209 \\
\hline $\mathrm{Pb}$ & & 33 & 6300 & 55 & 159 & - & 160 & 480 & 1100 \\
\hline Zn & & (15) & - & - & 1318 & 209 & 470 & 170 & - \\
\hline
\end{tabular}

a Virgin biomass; Dem = Demirbas [6]; L-S = Latva-Somppi [16].

mostly a function of the efficiency of gas cleaning for particulates. Fig. 2 shows data for an ESP unit fitted to a $66 \mathrm{MW}$ bubbling fluidised bed burning combined biomass and recovered solid fuel [15]. There is a maximum penetration of 4 to $6 \%$ around $1 \mu \mathrm{m}$ in particle size; similar results are presented by Strand et al. [17]. It has proved very difficult to obtain good mass balances for heavy metals over some commercial wood combustors e.g. Lind et al., 2003 [15], Kouvo and Backman, 2003 [18].

A reducing atmosphere around the burning fuel particles seems to accelerate heavy metal volatilisation because the formation of metal oxides, which are less volatile, is constrained due to lack of oxygen [2]. Consequently, a sub-stoichiometric atmosphere in the

Table 2

Distribution of elements in some boiler ashes (Li [27], Dahl [12] and Narodoslawsky [11]) ( $\mathrm{mg} \mathrm{kg}^{-1}$ or \%).

\begin{tabular}{|c|c|c|c|c|c|c|c|c|c|}
\hline \multirow[t]{2}{*}{ Metal } & \multicolumn{3}{|l|}{ Bottom ash } & \multicolumn{2}{|c|}{ Cyclone ash } & \multicolumn{3}{|l|}{ Filter ash } & \multirow{2}{*}{$\begin{array}{l}\text { Stack flyash } \\
\text { Nar } \\
(\%)\end{array}$} \\
\hline & $\begin{array}{l}\mathrm{Li} \\
\left(\mathrm{mg} \mathrm{kg}^{-1}\right)\end{array}$ & $\begin{array}{l}\text { Dahl } \\
\left(\mathrm{mg} \mathrm{kg}^{-1}\right)\end{array}$ & $\begin{array}{l}\text { Nar } \\
(\%)\end{array}$ & $\begin{array}{l}\mathrm{Li} \\
\left(\mathrm{mg} \mathrm{kg}^{-1}\right)\end{array}$ & $\begin{array}{l}\text { Nar } \\
(\%)\end{array}$ & $\begin{array}{l}\mathrm{Li} \\
\left(\mathrm{mg} \mathrm{kg}^{-1}\right)\end{array}$ & $\begin{array}{l}\text { Dahl } \\
\left(\mathrm{mg} \mathrm{kg}^{-1}\right)\end{array}$ & $\begin{array}{l}\mathrm{Nar} \\
(\%)\end{array}$ & \\
\hline As & 9.2 & $<3$ & 51.6 & 25.6 & 32.2 & 5.1 & 16 & 12.5 & 3.7 \\
\hline Ва & 535 & 330 & - & 671 & - & 206 & 2000 & - & - \\
\hline $\mathrm{Cd}$ & 1.1 & $<0.3$ & 6.4 & 2.3 & 47.0 & 1.9 & 3 & 36.0 & 10.7 \\
\hline Co & 6.7 & 2.5 & 68.2 & 11.5 & 26.1 & 6.4 & 8 & 4.4 & 1.3 \\
\hline $\mathrm{Cr}$ & 24.6 & 15 & 72.6 & 128 & 19.7 & 10.1 & 24 & 5.9 & 1.8 \\
\hline $\mathrm{Cu}$ & 12.8 & $<10$ & 61.9 & 31.6 & 21.7 & 18.9 & 60 & 12.6 & 3.7 \\
\hline $\mathrm{Fe}$ & 5230 & 19 & 70.4 & 8140 & 26.6 & 1990 & - & 2.3 & 0.7 \\
\hline Mn & 4865 & $<3$ & 64.7 & 7145 & 30.0 & 5020 & - & 4.1 & 1.2 \\
\hline $\mathrm{Ni}$ & 28.5 & - & 58.7 & 68.3 & 31.5 & 24.5 & 67 & 7.6 & 2.3 \\
\hline $\mathrm{Pb}$ & 29 & 95 & 65.9 & 36.1 & 34.2 & 23.4 & 49 & 41.7 & 12.4 \\
\hline $\mathrm{Ti}$ & 160 & 160 & - & 179 & - & 982 & - & - & - \\
\hline V & 99.2 & $<0.03$ & 71.5 & - & 22.8 & - & 140 & 4.4 & 1.3 \\
\hline $\mathrm{Zn}$ & 0.005 & & 23.2 & 252 & 45.2 & 61.7 & 480 & 24.4 & 7.2 \\
\hline $\mathrm{Hg}$ & & & 0.8 & 0.007 & 7.6 & 0.014 & 0.3 & 70.7 & 20.9 \\
\hline
\end{tabular}




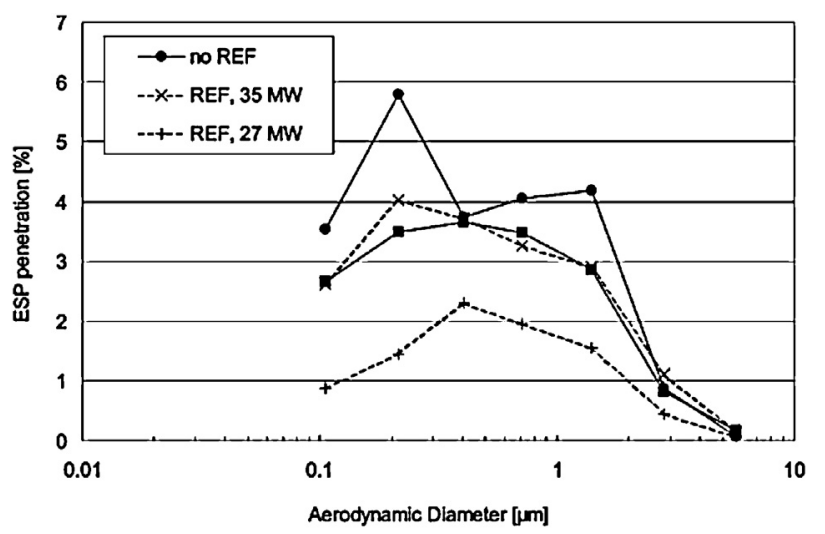

Fig. 2. Penetration through an ESP of fly ash particles from biomass combustion [15].

primary combustion zone will decrease the amount of heavy metals in the bottom ash. Most of the heavy metals do not have enough residence time in this type of combustor to diffuse out of the ash particle, and so remain. The amount of each in the exit flows from this process is governed by fluid dynamics and kinetics, and not by thermodynamics [19].

Yuan et al. (2005) [13] plot the concentrations of 6 metals (Pb, $\mathrm{Cd}, \mathrm{Zn}, \mathrm{Cu}, \mathrm{Hg}$ and $\mathrm{Cr}$ ) against particle size on particulates sampled on the upstream side of the air pollution control systems of five WTE plants in Taiwan which burn MSW. Most metals are concentrated on the fine fraction just under $1 \mu \mathrm{m}$ in particle size. It has been shown that any of the very fine ash which escapes sampling filters will be reported as vapour phase material [14].

From numerous studies it has been concluded that the partitioning will also depend on the type of furnace [20]. Zeuthen et al. (2007) [21] found that the metals $\mathrm{Cu}, \mathrm{Cd}, \mathrm{Hg}$ and $\mathrm{Pb}$ are significantly enriched in the finer aerosol particles formed in a $22 \mathrm{MWt}$ grate incinerator. Thermodynamic equilibrium is attained in larger particles from grate furnaces because of the length of exposure to high temperature of the particles. However, in fluidised beds there is insufficient time for equilibrium, and mass transport effects dominate. Under incineration conditions the most volatile metals, cadmium and lead need almost 10 minutes to diffuse out of an ash particle of the size found in FB incinerators i.e. $\sim 20 \mu \mathrm{m}$ [20].

In view of the complex chemistry and transport phenomena involved in metal partitioning, the results found under different conditions may vary. A table listing some experimentallydetermined values is given as Table 3 illustrates this. The results from Abanades et al. [22] are for MSW incineration, in which case the presence of high concentrations of chlorine would tend to increase the values of RE.

Note that Obernberger et al. [23] found that a decrease in both particle size and furnace temperature resulted in an increase in the concentration of Class II metals in/on the ash formed from cereal straw. When paper waste was burned at combustion temperatures below $1000^{\circ} \mathrm{C}$, the Class IIb metals $\mathrm{Cr}, \mathrm{Cd}$ and $\mathrm{Pb}$ were dispersed throughout the ash particles. In contrast at temperatures above $1250^{\circ} \mathrm{C}$, devolatilisation produced a depleted external shell of about $5 \mu \mathrm{m}$ thickness.

When pieces of willow were burned in a $12 \mathrm{MW}$ fluidized bed [24], the bulk of the flyash collected at $160^{\circ} \mathrm{C}$ was found to lie in the range- $10+2 \mu \mathrm{m}$. A smaller peak which had been formed by condensation at temperatures below $650^{\circ} \mathrm{C}$ had a mean size around $0.4 \mu \mathrm{m}$. The cadmium and lead in these samples was distributed between these two, but without concentrating in the finer group. In contrast, Latva-Somppi et al. [16] found significant enrichment of many metals in the flyash from bark combustion in a commercial fluidized bed.

The importance of trace metals being found in aerosols is demonstrated by the work of Jiménez et al. [25], when orujillo (a waste from olive oil production) was burned in an entrainment flow reactor at temperatures ranging from 1100 to $1450{ }^{\circ} \mathrm{C}$. The amount of excess air was varied to determine its effect on aerosol partitioning. Alkali sulfate and chloride accounted for virtually all of the mass in the submicrometer particles, which formed $3 \%$ of the total ash. All the metals studied, namely $\mathrm{Cr}, \mathrm{Mn}, \mathrm{Fe}, \mathrm{Co}, \mathrm{Ni}, \mathrm{Cu}, \mathrm{Zn}, \mathrm{Ga}, \mathrm{As}$, and $\mathrm{Pb}$ became highly concentrated in the submicrometer aerosols as a result of vaporisation and recondensation, particularly as the temperature increased.

It has been reported [26] that $\mathrm{Pb}(\mathrm{II}), \mathrm{Cd}(\mathrm{II})$, and $\mathrm{Hg}(\mathrm{II})$ ions especially are environmentally harmful to some plants. In an attempt to develop a process which conserves nutrient elements for subsequent agricultural application while sequestering heavy metals, Ljung and Nordin [26] carried out a thermodynamic analysis of all the species. The equilibrium behaviour of both the nutrient elements ( $\mathrm{Ca}, \mathrm{Mg}, \mathrm{K}, \mathrm{Na}, \mathrm{P}$ ) and heavy metals ( $\mathrm{Cd}, \mathrm{Cu}, \mathrm{Cr}, \mathrm{Pb}, \mathrm{Ni}, \mathrm{Zn}, \mathrm{As}$, $\mathrm{V}$ ) as functions of temperature was determined. The results indicate that $\mathrm{Cd}, \mathrm{Cu}, \mathrm{Pb}$, and possibly As and $\mathrm{Cr}$ may be volatilised, and thus separated through a hot cyclone $\left(800-850^{\circ} \mathrm{C}\right)$, still keeping all $\mathrm{Ca}$, $\mathrm{Mg}$ and $\mathrm{P}$, and $75 \%$ of $\mathrm{K}$ and $\mathrm{Na}$ in a condensed form in the cyclone ash.

A test of this approach was carried out by Li et al. [27] on a 12 $\mathrm{MW}_{\mathrm{e}}$ biomass-fired CFB, which incorporated a hot cyclone before a fabric filter for particle removal. A mixed fuel of

cotton stalk, bark, and a few rice husks (4:5:1; dry weight basis) was used during the test. The median sizes of the ash were about 12 , 85 and $300 \mu \mathrm{m}$ diameter respectively for the filter, cyclone and bottom ash. Some elemental concentrations are reproduced in Table 2, where most elements are at higher concentrations in the cyclone ash than in the filter ash.

Also shown in Table 2 are values measured by Dahl et al. [12] in a $32 \mathrm{MW}$ fluidised bed boiler firing a mixture of woodchips, sawdust, bark and peat. The values for most elements in the two streams are of the same order as those reported by Li et al. About $90 \%$ of the heavy metals in the flyash were located in the finest $<74$ micron fraction. Similarly they reported mainly (84-92\%) to the smallerrange $0.5<\mathrm{d}_{\mathrm{p}}<2 \mathrm{~mm}$ fraction in the bottom ash.

The concentrations of common elements in the fly ash generated by the combustion of clean pinewood were analysed for bioavailability [28]. Most nutrient elements were found to be in a readily available form, whereas the heavy metals were less bioavailable. It was concluded that the ash was suitable for land application, which is in contrast to the position in Denmark, where use of ash

Table 3

Measured Enrichment Factors in flyash for Biomass Combustion.

\begin{tabular}{|c|c|c|c|c|c|c|c|c|c|c|}
\hline Author & Fuel & $\begin{array}{l}\mathrm{Cr} \\
\text { IIc }\end{array}$ & $\begin{array}{l}\text { Co } \\
\text { IIb }\end{array}$ & $\begin{array}{l}\mathrm{Ni} \\
\mathrm{IIb}\end{array}$ & $\begin{array}{l}\text { Zn } \\
\text { IIb }\end{array}$ & $\begin{array}{l}\text { Mo } \\
\text { IIa }\end{array}$ & $\begin{array}{l}\text { As } \\
\text { Ila }\end{array}$ & $\begin{array}{l}\mathrm{Pb} \\
\text { Ila }\end{array}$ & $\begin{array}{l}\text { Cd } \\
\text { Ila }\end{array}$ & $\begin{array}{l}\mathrm{Hg} \\
\text { III }\end{array}$ \\
\hline Abanades [22] & MSW & 2.5 & 0.9 & 0.5 & 0.8 & - & 2.0 & 10 & 52 & $>30$ \\
\hline Narod'sky [11] & Forest res & 0.7 & 4.2 & 1.3 & 5.7 & 1.2 & 1.7 & 12 & 25 & 186 \\
\hline Obernb'er [23] & Straw & $\sim 1$ & 3.2 & $\sim 1$ & 13 & - & - & 15 & 27 & - \\
\hline Stanmore [32] & Forest res & 2.1 & & 9 & 3.0 & - & 1.0 & 13 & 33 & $>90$ \\
\hline Dah [22]l & F res + peat & 1.6 & & 3.5 & & $>2$ & $>5.3$ & $>16$ & $>10$ & $>10$ \\
\hline
\end{tabular}



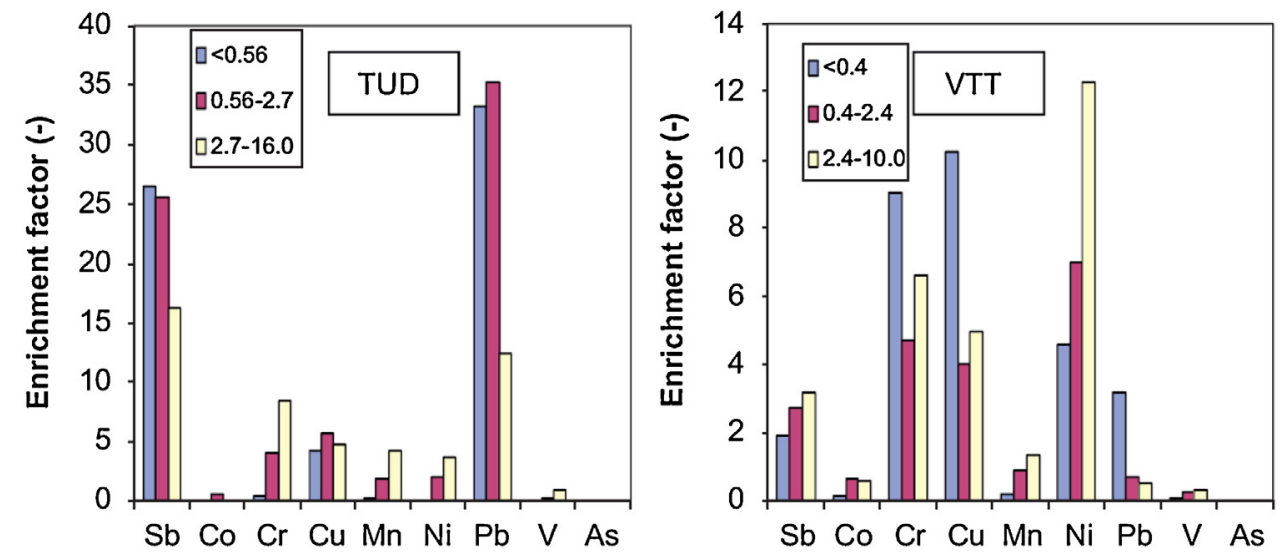

Fig. 3. Toxic metal enrichment factors for contaminated wood in BFBs. as a function of particle size [33].

containing similar amounts of total cadmium is prohibited. It should be noted that the type of procedure used can strongly influence leaching behaviour e.g. deionised water vs acetic acid [27].

\section{Results and discussion}

Each of the contaminated materials will now be considered in turn.

\subsection{Wood waste}

\subsection{1. - Demolition and other contaminated timber}

The mineral matter content of natural woody materials is so low, see Table 1 , that normal emission limits are easily met. When the small amount of mineral matter in natural biomass is considered, the flyash burden would be low and the overall metal emissions minimal. As an example, the flyash from a WtE plant burning straw was found to contain $14 \mathrm{mg} \mathrm{kg}^{-1}$ of chromium and $11 \mathrm{mg} \mathrm{kg}^{-1}$ of cadmium [29]. However, Narodoslawski and Obernberger [11] single out cadmium as the major health concern of burning clean timber. They claim that wood chip ash and bark ash will meet the Austrian emission limits, but that flyash from the burning of sawdust, which has a smaller fuel particle size, will not.

The quantity of recycled wood burned in Sweden is estimated by Krook et al. [7] to be of the order of 500 - 600,000 tpa, giving an estimated 30,000 tpa of ash. For the three most elevated metals, namely lead, chromium and arsenic, the relative concentration ratios over virgin wood are 480, 960 and 1800 respectively. The absolute values noted by Hwang et al. [30] for a highly contaminated sample are $\mathrm{Cd} 1.0, \mathrm{Cr} 2532, \mathrm{Cu} 422, \mathrm{~Pb} 673$ and $\mathrm{Zn} 2593 \mathrm{mg} \mathrm{kg}^{-1}$ in the char after pyrolysis at $500^{\circ} \mathrm{C}$.

Grasso and Atkins [31] report on an extensive study of recycled wood in the USA, and note that it "must usually be separated from a mixed bulky waste stream and processed into a suitable fuel". They quote the sources as mixed construction and demolition debris, railroad sleepers (ties), telephone poles, pallets and shipping containers. The material contains physically-separable contamination such as asphalt, bricks, tiles, glass, flooring etc., as well as chemically-contained compounds like creosote, preservatives, glues, paints, resins and preservatives.

When a FB boiler operating in a paper plant was fed with $50 \%$ demolition timber to supplement the forest waste fuel, the emission limits barely increased [32]. This came about because the timber was carefully selected, and averaged As $0.4 \mathrm{mg} \mathrm{kg}^{-1}, \mathrm{Cd} 2.4$, $\mathrm{Cr} 22, \mathrm{Cu} 40, \mathrm{Ni} 4, \mathrm{~Pb} 19$ and $\mathrm{Zn} 180 \mathrm{mg} \mathrm{kg}^{-1}$. These figures are orders of magnitude below those in the US study, and are similar to those for virgin timber
Moderately contaminated wood was burned by Kahn et al. [33] in two bubbling fluidised beds, both on the lab scale and the pilot scale. The $1 \mathrm{MW}_{\mathrm{t}}$ TUD pilot combustor was fitted with a cyclone with a $10 \mu \mathrm{m}$ cut diameter, while the $20 \mathrm{~kW}_{\mathrm{t}}$ VTT lab unit was fitted with a fabric filter. The total ash emissions were about $11 \mathrm{mg} \mathrm{Nm}^{-3}$ for the former and $2 \mathrm{mg} \mathrm{Nm}^{-3}$ for the latter. Most of the material was in the $0.4-2.4 \mu \mathrm{m}$ range for the pilot scale emissions, but $<0.4 \mu \mathrm{m}$ for the lab scale with a fabric filter. The values of RE in the fugitive particulate emissions for the two units are reproduced in Fig. 3. Antimony and lead show extremely high values in the TUD unit, while other elements are also represented in the finer particles from the VTT fabric filter.

A study of a fluidised bed combustor burning wood waste by Kouvo et al. (2003) [18] demonstrated that the situation is dynamic and far from steady-state. The bed can act as a "buffer" for some elements, storing them and then later releasing them into the gas phase when the concentration of the element in the feed falls. This data includes both gaseous and particulate matter, with volatile metals like cadmium being concentrated in the- $10 \mu \mathrm{m}$ particles.

It was reported by Lima et al. (2008) [29] that Cd is present mostly as carbonates in MSW ash, but as oxide in straw ash. Chromium was found principally as oxide in both ashes. The difference was attributed to a combination of the fuel composition and the flue gas temperature.

Co-firing of creosote and PCP-treated timber with coal was examined by Freeman et al. [34] in a pilot scale pulverised fuel combustor, which simulated conditions in a utility boiler. Tests at $10 \%$ contribution from biomass on an energy basis showed that the concentrations of metals ( $\mathrm{Sb}, \mathrm{As}, \mathrm{Cd}, \mathrm{Co}, \mathrm{Pb}, \mathrm{Mn}, \mathrm{Hg}, \mathrm{Ni}, \mathrm{Se}$ ) in the fluegas upstream of the gas cleaning system were little changed from the baseline Upper Freeport coal.

\subsubsection{Phytoremediation scavengers (phytoextractors)}

Phytoremediation of contaminated sites is achieved by planting hyperaccumulating plants which selectively absorb the contaminants. There is a range of such plants, which may concentrate the pollutant in the roots, stem or leaves. Although the plants may extract metals from the soil, the long-term disposal of the elements depends on the subsequent treatment of the biomass. Thermal methods are the obvious choice, but little information is available on this aspect, as most papers report on the efficiency of take-up by the plant.

Site operation and landfilling is reviewed by Nagendran et al. [35]. In a study of legume and cereal crops, Wang et al. [36] measured the bioconcentration factors for a range of metals and plant species. Significant linear correlations were found between plant 
and soil metal concentrations, and some of the values were large $(\sim$ 1000 times). On sites with multiple metal contamination, it would be safer to grow maize or rapeseed than wheat or legumes

A report by Scholz and Ellerbrock [3] on the use of a range of plants for energy cropping gives an idea of the normal range of metals found in biomass subjected to systematic fertilising and harvesting over a number of years. The values reported fall in the ranges: $\mathrm{Cd} 0.3-2.2 ; \mathrm{Pb}<1$ to $\sim 4 ; \mathrm{Cu} 2.6-22.6$ and $\mathrm{Zn}$ $15-135 \mathrm{mg} \mathrm{kg}^{-1}$. These should be compared to the much higher remedial values given in Table 4 .

The hyperaccumulating ability of 12 plant species for metals was examined by Nanda Kumar et al. [37]. They found that the best four were able to incorporate over $100 \mathrm{mg} \mathrm{kg}^{-1}$ of lead in their roots. Brassica juncea was also able to concentrate $\mathrm{Cr}^{6+}, \mathrm{Cd}, \mathrm{Ni}, \mathrm{Zn}$, and $\mathrm{Cu}$ in the shoots by factors of 58-, 52-, 31 -, 17-, and 7-fold respectively,from a substrate containing sulfates and phosphates as fertilizers. The take-up was especially rapid in new shoots in the short term. After 14 days the concentrations in the shoots of Ni were $3000 \mathrm{mg} \mathrm{kg}^{-1}$, with $\mathrm{Zn} 1700, \mathrm{~Pb} 830$ and $\mathrm{Cr}^{6+} 200 \mathrm{mg} \mathrm{kg}^{-1}$. The rate of absorption fell off as the plants grew. Mellem et al. [8] found that Amaranthus dubius could remove $\mathrm{Hg}$ and $\mathrm{Cr}$ from contaminated soil into its roots, but $\mathrm{Cr}$ could not be translocated to the shoots. $\mathrm{Pb}, \mathrm{As}$, $\mathrm{Ni}$ and $\mathrm{Cu}$ were also removed, but to a lesser extent.

An evaluation of disposal options by Sas-Nowosielska et al. [38] examined the merits of composting, compacting, pyrolysis and ashing (combustion). It was found that the combustion route was most environmentally effective, at a cost of $\notin 180-220$ per tonne in 2004 . They lament that there is little information given on this application.

Low temperature pyrolysis is proposed as a disposal technique by Stals et al. [39], and as a precursor to combustion/gasification by Keller et al. [40]. The thermal technique proposed by Stals et al. is flash pyrolysis in a fluidised bed, where the feed is heated rapidly to cause devolatilisation without excessive destruction of the organic molecules. The contaminant levels for a willow wood are given in Table 4 . At bed temperatures of 350 and $450^{\circ} \mathrm{C}$, the retention of metals in the pyrolysis oil is less than $4 \%$. The char retains most of the inorganics, but it was difficult to close a mass balance because the sand of the bed reacted with some of the metals.

Keller et al. [40] found that pyrolysis under reducing conditions was a better method than incineration under oxidising conditions to increase the volatilisation of, and hence the subsequent recovery of $\mathrm{Cd}$ and $\mathrm{Zn}$ from willow (Table 4). These results imply that staged combustion would be a suitable process for producing an ash which meets environmental limits as a soil additive.

In comparison, the willow trialled by Vervaeke et al. [41] was only lightly contaminated, having $\mathrm{Cd}, \mathrm{Cr}$ and $\mathrm{Pb}$ present at about $4 \mathrm{mg} \mathrm{kg}^{-1}, \mathrm{Cu} 6, \mathrm{Ni} 2$ and $\mathrm{Zn} 150 \mathrm{mg} \mathrm{kg}^{-1}$. The wood was gasified in a small downdraft gasifier to generate $1 \mathrm{kWh}$ per $\mathrm{kg}$ of feed. With the low level of contamination, the bottom ash met the Flemish disposal limits, except for zinc, see Fig. 4.

Gupta et al. [42] trialled four types of plant on land which had received large amounts of tannery waste. The waste was heavily contaminated with heavy metals, particularly chromium at $7.5 \mathrm{~g} \mathrm{~kg}^{-1}$. For the plants tested, the chromium content ranged from 100 to $400 \mathrm{mg} \mathrm{kg}^{-1}$, while copper was $20-30 \mathrm{mg} \mathrm{kg}^{-1}$, and zinc $60-70 \mathrm{mg} \mathrm{kg}^{-1}$. The remainder of the metals measured viz. $\mathrm{Pb}$, $\mathrm{Ni}, \mathrm{Cd}$ and $\mathrm{Co}$ all fell below $15 \mathrm{mg} \mathrm{kg}^{-1}$. At these concentrations, apart from chromium, the biomass is not particularly contaminated cf Table 1.

The behaviour of arsenic during the incineration of contaminated $P$. vittata was studied by Yan et al. [43]. With an initial concentration of $1170 \mathrm{mg} \mathrm{kg}^{-1}$, the material lost approximately $24 \%$ of the As when the combustion temperature was held at $800^{\circ} \mathrm{C}$, and the loss was approximately linear with temperature below this point. A project to remediate a minesite contaminated

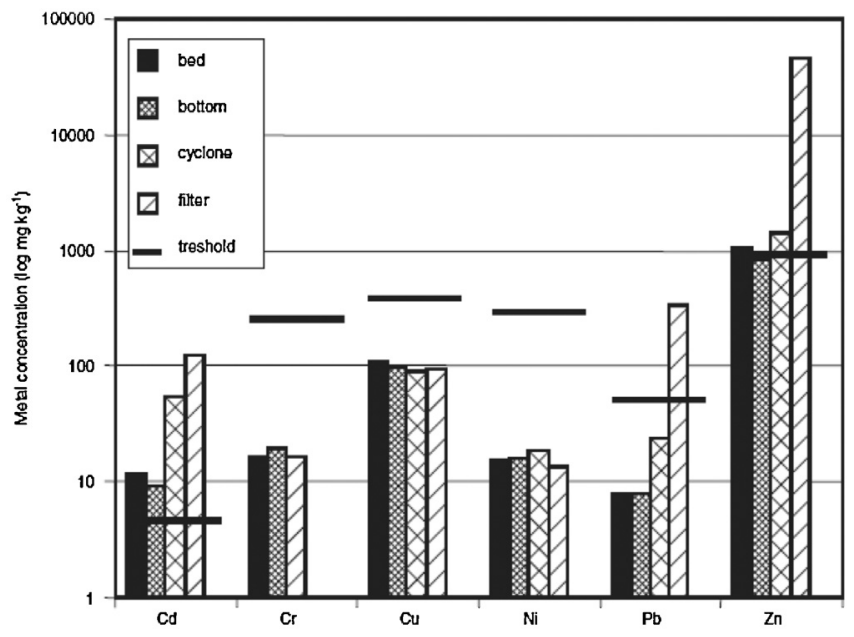

Fig. 4. Metal concentrations in various gasifier ashes from willow [41].

with radionuclides by means of either sunflower, Triticosecale (a wheat/rye cross) or Indian mustard showed that almost all uranium scavenged by the plants was retained in the ash [44].

\subsubsection{Chromated copper arsenate (CCA) wood}

It was estimated that in 2005 the world-wide wood preservation industry treated approximately 30 million cubic metres of wood, consuming some 500000 tonnes of preservative chemicals [45]. Approximately two thirds of this volume was treated with chromated copper arsenate (CCA). CCA pine enjoyed extensive use from the 1950s onwards, but has been restricted in application since. Disposal projections estimated the peak disposal rate in the USA occurred in 2008, at 9.7 million $\mathrm{m}^{3}$ [46].

The amount of metals present in CCA-treated pine chips in Sweden is reported by Lundholm et al. (2008) [47] to be $2.13 \mathrm{~g}$ per kg of wood (dry basis) for arsenic, 4.78 for chromium and $2.60 \mathrm{~g} \mathrm{~kg}^{-1}$ for copper. Similar figures are reported for Australia [48] and the USA [49]. In contrast, the figures for Denmark are much lower at $0.10,0.32$ and $0.22 \mathrm{~g} \mathrm{~kg}^{-1}$ [5]. The figure for chromium in random samples purchased in the state of Florida USA varied from 1.3 to $15.8 \mathrm{~g} \mathrm{~kg}^{-1}$ [50].

A review by Helsen and Van den Bulck [45] examined various disposal technologies and concluded that co-combustion or high temperature gasification were the preferable choices. However Solo-Gabriele and coworkers found that from laboratory burns that the metal concentrations $(\mathrm{Cr}+\mathrm{Cu}+\mathrm{As})$ in the bottom ash could be as high as $36 \%$ of the ash by weight when the metal retention levels were high $\left(40 \mathrm{~kg} \mathrm{~m}^{-3}\right)$. Even burns with $5 \%$ of CCA wood in the sample could leach enough arsenic to be characterised as a hazardous waste under US regulations.

Song et al. [50] note that only 0.7 to $4 \%$ of the chromium present in their samples and the ash generated from them was found as $\mathrm{Cr}^{6+}$. Although the treatment components are simple, inorganic reactions during the wood preservation process produce complicated inorganic compounds and complexes [51]. They found that the ash produced by burning a large sample in a furnace with a cyclone temperature of $800-900{ }^{\circ} \mathrm{C}$ contained $35 \mathrm{~g} \mathrm{~kg}^{-1}$ of As, $69 \mathrm{~g} \mathrm{~kg}^{-1}$ of $\mathrm{Cu}$ and $62 \mathrm{~g} \mathrm{~kg}^{-1}$ of $\mathrm{Cr}$. The ash yield was around $2 \%$, so that much of the metals was retained in the ash.

In most studies available, the disposition of the ash under similar combustion conditions was the same. With CCA wood burned in an open pit, some of the metals are released as vapour, and then condensed onto the flyash [49]. They found that over $99 \%$ of the $\mathrm{Cd}$ and $\mathrm{Cu}$ remain in the bottom ash,and state "The partitioning of $\mathrm{As}, \mathrm{Cr}$, and $\mathrm{Cu}$ between the emitted fly ash and residual ash is 
Table 4

Metal loadings on willow used for phytoextraction [38].

\begin{tabular}{|c|c|c|c|c|c|c|c|}
\hline \multirow[t]{2}{*}{ Element ( $\left.\mathrm{mg} \mathrm{kg}^{-1}\right)$} & \multicolumn{2}{|c|}{ Willow (Stals [39]) } & \multicolumn{3}{|c|}{ Salix Willow (Keller [40]) } & \multirow[t]{2}{*}{ Sufficient or normal } & \multirow[t]{2}{*}{ Excess or toxic } \\
\hline & Stems & Leaves & Wood & $\begin{array}{l}\text { Ash } \\
\text { Oxid }\end{array}$ & Reduc & & \\
\hline $\mathrm{Zn}$ & 822 & 4640 & 1138 & 7293 & 442 & $27-150$ & $100-400$ \\
\hline Cd & 41 & 80 & 7.3 & 2 & 0 & $0.05-0.2$ & $5-30$ \\
\hline $\mathrm{Cu}$ & 11.4 & 15 & 53 & 171 & 58 & $5-30$ & $20-100$ \\
\hline $\mathrm{Pb}$ & 26 & 14 & - & - & - & $5-10$ & $30-300$ \\
\hline
\end{tabular}

examined and thermochemical predictions from the literature are used to explain the observed behaviour. Results indicate a unimodal fly ash PSD between 0.1 and $1.0 \mathrm{im}$ diameter. In addition to a large carbonaceous component, between 11 and $14 \%$ of the As present in the burned CCA treated wood was emitted with the air emissions, with the remainder present in the residual ash. In contrast, less than $1 \%$ of both the $\mathrm{Cr}$ and $\mathrm{Cu}$ present in the wood was emitted with the air emissions".

Under severe conditions at elevated temperatures, Lundholm et al. [47] found that the arsenic is increasingly lost from the ash residues, with only $20 \%$ remaining at $1000^{\circ} \mathrm{C}$, see Fig. 5 . On the other hand $80-90 \%$ of the chromium is retained at temperatures up to $1000^{\circ} \mathrm{C}$, and copper was virtually non-volatile under the combustion conditions, which is in keeping with thermodynamic considerations.

\subsection{Sewage and Paper sludge}

\subsection{1. - Sewage sludge}

A comprehensive study of the European scene was carried out by Werther and Ogada [9], who estimated that in 2005 the rate of production would attain around $10 \mathrm{Mt}$ of dried sludge per annum. As indicated by Table 1, there is a significant presence of heavy metals in the raw sludge. Werther notes the concentrations of heavy metals in sewage sludges thus depend on the industrial activities around the source of sludge. The heavy metals exist in sewage sludge in the form of hydroxides, carbonates, phosphates, silicates and sulphates. They are incorporated in the solid matter of the sludge and remain with the sludge during wastewater treatment processes'.

Over $40 \%$ of the sludge in Europe was incinerated, so that a great deal of effort has been expended on tracking the fate of metals during combustion [30]. A study of the behaviour of balls of raw sludge by Cui et al. [52] notes that when the burning of volatiles had raised the temperature of the solid above the ash fusion point, small droplets of molten ash covered the surface of the pellet. The droplets then tended to agglomerate during the char combustion phase, so that shrinkage and ash agglomeration were the main

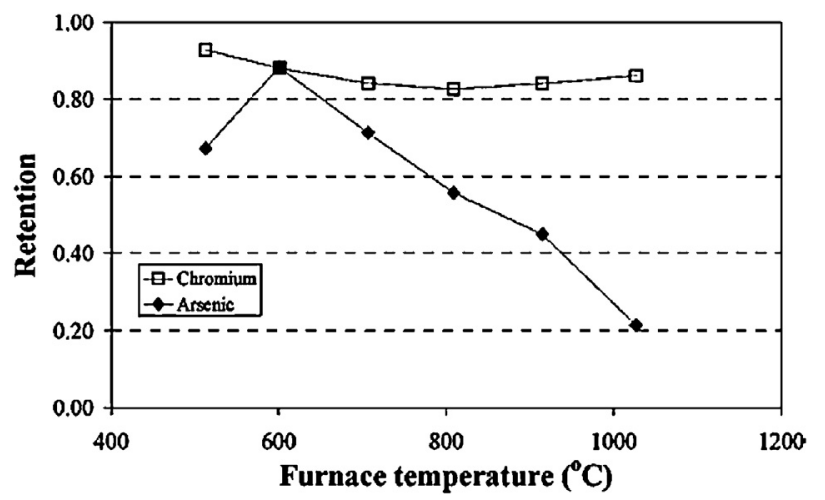

Fig. 5. Partitioning of CCA elements during combustion [47]. contributors to volume reduction. The history of a burning pellet is shown in Fig. 6, where the fused nature of the residue is evident.

The aerodynamics of the combustor influences the loss of particulates, and hence metals. For rotary and multiple hearth furnaces, the fusion of the ash restricts entrainment. An average of only about $20 \%$ and $10 \%$ of the feed can be expected in each instance (Werther). With fluidised bed combustors however, almost all the ash is lost as flyash.

A careful mass balance sampling operation by Van de Velden et al. (2008) [53] on a $4.4 \mathrm{~m}$ diameter commercial municipal sewage sludge FB incinerator showed that the overwhelming proportion of all heavy metals released was present in the flyash. The three most volatile metals, $\mathrm{Hg}, \mathrm{Pb}$ and $\mathrm{Cd}$ showed a greater tendency to be lost to the stack, but the emissions were within the statutory limit. However the flyash from the ESP exceeded all heavy metal concentrations for direct disposal to soil.

In drop tube furnace trials on dried sludge, Han et al. [54] found that hollow cenospheres were formed. Most of the lead and cadmium was contained in the fine particles $(<1 \mu \mathrm{m})$, whereas the variation in chromium concentration with particle size showed a trend similar to the total particle mass distribution of the ash particles. Similar behaviour was exhibited in a small fluidised bed operated at $700-800^{\circ} \mathrm{C}[19]$, where most of the heavy metals had insufficient residence time at temperature to diffuse out of the ash particles. Only cadmium and sometimes lead showed exceptional decreases in concentration.

Elled et al. [55] report similar findings with a higher concentration of metals in the finer particles. From experimental data and thermodynamic calculation, Han et al. [54] note that lead volatilises to a significant extent around $400^{\circ} \mathrm{C}$, arsenic around $600^{\circ} \mathrm{C}$ and copper and zinc around $800^{\circ} \mathrm{C}$.

A laboratory-scale fluidised bed was used by Shao et al. [56] to study metal partitioning from 7 sludge samples at temperatures around $900^{\circ} \mathrm{C}$. They found that zinc was the metal most represented in the bottom and fly ashes, at $1600-1900$ and $2200-2900 \mathrm{mg} \mathrm{kg}^{-1}$ respectively. The average concentrations of the metals studied followed the order $\mathrm{Zn}>\mathrm{Cu}>\mathrm{Mn}>\mathrm{Cr}>\mathrm{Ni}>\mathrm{Pb}>\mathrm{V}>\mathrm{Cd}>\mathrm{Co}$. Cobalt and copper were found mostly in the bottom ash, while lead and zinc were found mostly in the flyash.

The emission of heavy metals was low at a commercial Australian multiple hearth plant [32]. For instance, $\mathrm{Cd}$ and Ni were present at concentrations which average 0.02 and $<0.14 \mathrm{mg} \mathrm{Nm}^{-3}$ respectively. These are at least an order of magnitude below the regulatory limits, and compare with typical values in the original sludge of 3.8 and $39 \mathrm{mg} \mathrm{kg}_{\mathrm{dr}}$ matter ${ }^{-1}$. Note that the relativity between the metal concentrations was retained.

In respect to mercury, which may be present in fluctuating amounts, the control strategies depend on the form in which the metal is present [9].Wet scrubbing will remove ionic mercury, and some reagents may be added to form precipitates. Activated carbon may be necessary for emissions high in elemental mercury.

Luts et al. [57] carried out extensive trials on the co-combustion of dried SS with coal in a $130 \mathrm{MW}_{\mathrm{e}}$ pf boiler at a Flemish power station. The contribution of the SS was 2.5 to $7.6 \%$ by mass of the 

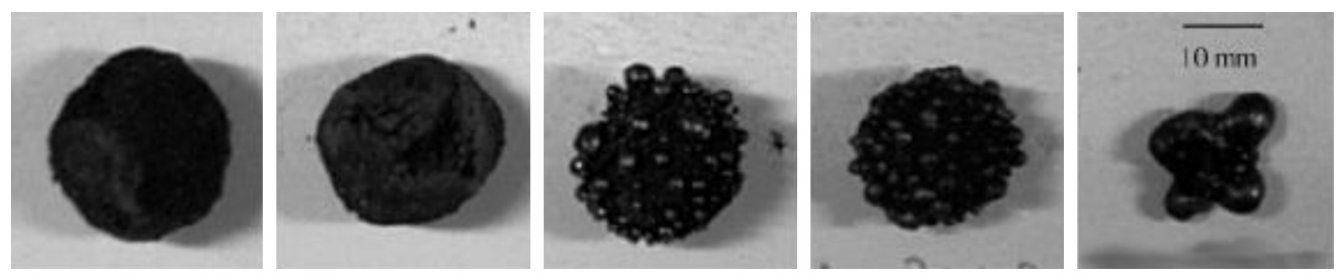

Burning time

Fig. 6. History of a burning sphere of raw sewage sludge [71].

dry solid feed. Despite the sludge having high levels of contamination with heavy metals, only the concentration of zinc was elevated significantly in the ash. The metals had been stabilised at the high flame temperatures and easily met leaching requirements. A similar result is reported by Spiethoff et al. [58], who found only a modest increase in heavy metal content $(\mathrm{Pb}, \mathrm{Cd}, \mathrm{Hg})$ in the flyash when up to $25 \%$ by mass of sewage sludge was co-fired with coal in a pilot scale furnace.

\subsubsection{Paper sludges}

Sludges are generated by the paper industry when the recovery of recycle material is undertaken, and contain fillers, inks and general crud as well as cellulose fibres. The sludge has a soft, pastelike consistency, contains $65-84 \%$ moisture, and a reported heating value in the range 0.7 to $1.8 \mathrm{MJ} \mathrm{kg}^{-1}$ [59]. Kaolinite and calcite are the major ash-forming minerals in the sludge, contributing $40 \%$ each [16]. Kozinski and Zheng [60,61] found that the sludge from de-inking operations was composed of long cylindrical fibres mainly between 15 and $20 \mu \mathrm{m}$ in diameter with some up to $50 \mu \mathrm{m}$, and lengths between 200 and $500 \mu \mathrm{m}$.

As far as heavy metals are concerned, Louhimo et al. [62] conclude from experience with a bubbling fluidised bed burning a mixture of sludge, bark and peat that "the most important factor in achieving low heavy metal emissions is having an effective dust cleaning system". The major metal emissions when burning equal masses of woodwaste, sludge and peat were $\mathrm{Cu}$ at $30 \mu \mathrm{g} \mathrm{MJ}^{-1}, \mathrm{~Pb}$ 37 and $\mathrm{Cr} 20 \mu \mathrm{g} \mathrm{MJ}^{-1}$. The values reported by Hwang et al. [30] for one sludge are $\mathrm{Cd}$ 2.0, $\mathrm{Cr}$ 30.2, $\mathrm{Pb} 100, \mathrm{Zn} 332$ and $\mathrm{Cu} 900 \mathrm{mg} \mathrm{kg}^{-1}$ in the ash.

The distribution and leaching of metals from sludge ash was examined by Kozinski and Zheng [60,61], using a de-inking sludge with added $\mathrm{Pb}, \mathrm{Cd}$ and $\mathrm{Cr}$. At combustion temperatures below $1000^{\circ} \mathrm{C}$, typical of waste systems, they found that the concentrations of the heavy metals in the particle core and in the surface region were comparable. At higher temperatures the metals tended to be lost from the exterior layers. The metals in the ash did not leach when the reaction temperature was above $1000^{\circ} \mathrm{C}$; below this temperature the tendency was $\mathrm{Cr}>\mathrm{Cd}>\mathrm{Pb}(=0)$.

Rink et al. [63] burned a metal-impregnated waste based on cotton fibres in a bubbling fluidised bed. The metal concentrations were $\mathrm{Cd}-350 \mathrm{ppm}$; $\mathrm{Cu}-450 \mathrm{ppm}$; $\mathrm{Pb}-480 \mathrm{ppm}$; and $\mathrm{Ni}-480 \mathrm{ppm}$. The bed was atypical in that a pilot gas flame above the bed raised the gas temperature to $1380^{\circ} \mathrm{C}$ in the splash zone. This caused the flyash particles to fragment and fuse into glassy spheres. The alkali and alkaline earth metals in the ash created a multilayer external shell (4-6 $\mu \mathrm{m}$ in thickness) which encapsulated the heavy metals distributed in discrete pockets towards the core of the particle.

Eldabbagh et al. [64] doped a comparatively clean sludge from the paper industry with cadmium and chromium, and burned it at $750^{\circ} \mathrm{C}$ in a pilot-scale fluidised bed. The structure of the $15 \mathrm{~mm}$ particles changed from a loose fibrous mass to a porous semifused sphere. The distributions of $\mathrm{Cd}$ and $\mathrm{Cr}$ were relatively uniform across the radius of the particles. When the bed was operated with a high temperature zone $\left(1180^{\circ} \mathrm{C}\right)$, the particles were fused, and the surface was depleted of the two heavy metals.

A number of waste fuels were burned by Corella et al. in an entrainment combustor, which was intended to simulate conditions in a fluidised bed. The waste fuels were co-combusted with bark from the paper industry, and included de-inking sludge. The trace elements analysed were $\mathrm{Cd}, \mathrm{Cr}, \mathrm{Mn}, \mathrm{Ni}, \mathrm{Pb}$, Se and $\mathrm{Zn}$. In all runs, bottom ash accounted for more than $90 \%$ of the total ash recovered, so that apart from $\mathrm{Cd}$ and $\mathrm{Hg}$, all elements were largely retained in this ash, since the relative enrichment values were below 2 .

A DTA was employed by Zheng and Kozinski $[60,61]$ to combust de-inking waste containing approximately $20 \%$ ash from a paper recycling operation. The material was fibrous in nature and was spiked with chromium, cadmium and barium. The material was oxidised under a rising temperature regime to $1500^{\circ} \mathrm{C}$, and then either slowly cooled, or quenched. At these high temperatures, the ash melted.

The leachability of $\mathrm{Cr}, \mathrm{Cd}, \mathrm{Pb}$ and Ba from ash particles formed during natural cooling was significantly higher than the leachability of the same metals from ash formed during quenching. The extent leaching of $\mathrm{Cr}$ and $\mathrm{Cd}$ was 8.9 and $5.3 \%$ for naturally cooled particles respectively; and 0.2 and $0.05 \%$ for quenched particles. Virtually no $\mathrm{Pb}$ and $\mathrm{Ba}$ were leached from quenched ash, and the figures for naturally cooled ash were 13.4 and $0.15 \%$.

\subsection{Chicken litter}

Chicken litter is a mixture of wood chip (or straw), faecal matter, spilled feed, dead birds, eggs, feathers etc., which is removed from the floors of chicken houses. It must be replaced regularly to maintain cleanliness and health. In 2008 broiler production in the USA accounted for approximately 8882 million birds [65], and it is estimated that about 44.4 million tonnes of poultry manure was produced in that year. This waste material contained 2.2 million tonnes of nitrogen, 0.7 million tonnes of phosphorus and 1.4 million tonnes of potassium.

Combustion is increasingly being used as a disposal route. Using thermogravimetric analysis (TGA), Whiteley et al. [66] found that the combustion process proceeds in four stages, (I) release of absorbed water and ammonia $\left(25-150^{\circ} \mathrm{C}\right)$; (II) devolatilization $\left(150-350^{\circ} \mathrm{C}\right)$, (III) char precombustion $\left(350-500^{\circ} \mathrm{C}\right)$, and (IV) rapid char combustion $\left(500-650^{\circ} \mathrm{C}\right)$.

Abelha et al. [67] found that provided the moisture content of chicken litter was below $25 \%$, autothermal combustion could be maintained in a fluidised bed. They report that 'In general, the amounts of heavy metals present in the poultry litter were not found to be high enough to render a great concern, and the ashes could be used for agricultural purposes because (1) they were found to contain traceable amounts of organic compounds and (2) the leachability of heavy metals were relatively low'. 
Metal concentrations in the bed ash produced in a pilot scale fluidised bed by Jia et al. [68] are not reported; and in the flue gas were at or below the limit of detection. However, they were significantly represented in the particulates. For example, Ni was present at $39,000 \mathrm{mg} \mathrm{kg}^{-1}, \mathrm{~Pb}$ at 170 and As at $117 \mathrm{mg} \mathrm{kg}^{-1}$. Obviously this material could not be used directly in agriculture, and the authors recommend co-combustion with coal.

The trials of Corella et al. simulating FB combustion included chicken litter, which behaved like all other fuels by retaining most of its nickel, and the selenium levels were always below the limit of quantification.

The stabling of horses produces a similar material to chicken litter, consisting of a mixture of wood shavings and manure. About $20 \mathrm{~m}^{3}$ of the waste, which differs little in properties from virgin wood, is produced for each horse per annum [69]. When a sample was subjected to combustion its behaviour was similar to chicken litter, except for elevated $\mathrm{Cr}$ and $\mathrm{Ni}$ levels.

\subsection{Spent pot liner}

The cathodic carbon liners of the electrolysis cells in aluminium smelters need to be periodically replaced. Known as spent pot liner, it is produced in quantities around 500,000 tpa world-wide. The World Bank Group Pollution Handbook (WBG) [70] states "An aluminium smelter produces $40-60 \mathrm{~kg}$ of mixed solid wastes per tonne of product, with spent cathodes (spent pot and cell linings) being the major fraction".

The cryolite $\left(\mathrm{Na}_{3} \mathrm{AlF}_{6}\right)$ from the bath impregnates the carbon, so that the linings finally consist of $50 \%$ refractory material and $50 \%$ carbon. Over their useful life, the carbon "contains aluminium and silicon oxides (averaging 16\% of the carbon lining), fluorides (34\% of the lining), and cyanide compounds" (WBG). The latter are present at about $400 \mathrm{ppm}$ on average, but may be much higher. The leachates from landfill disposal sites have been found to contain up to $575 \mathrm{mg} \mathrm{l}^{-1}$ of fluoride.

No analyses for heavy metals have been uncovered from this review, and no reports of combustion trials. When subjected to thermal processing, the material is known to liberate hydrogen fluoride, hydrogen cyanide and sulphur oxides. Any heavy metals present will report with the refractory material as ash, but the major environmental concern is the fluoride content.

\subsection{Role of metal alkali}

In the previous sections the focus was on alkaline and transition metals behaviour. An abundant literature is available on the role of alkalis on the conversion of biomass during the combustion, pyrolysis and gasification processes. A summary of data for a range of biomass considered is presented in Arrhenius form by Klose and Wolki [71]. The degree of conversion is linked with the catalytic effet of alkalis. As alkali compounds have high vapour pressures, they tend to evaporate during extended use at gasifier and combustion temperatures.

The catalytic role has been observed by other authors [72-77]. An important study of the catalytic action of some metals and their dispersion in char during gasification was undertaken by Devi et al. [72,73] and Huang et al. [77] using oxygen as the gasifying medium. They found that the temperature at which the chars were prepared influenced the chemical form of the metal, with potassium being significantly affected. Above $650^{\circ} \mathrm{C}$, potassium changed from being predominantly in the $\mathrm{KOH} / \mathrm{K} 2 \mathrm{CO} 3 / \mathrm{K} 2 \mathrm{O}$ state to being dispersed as metal (initially as vapour) throughout the carbon matrix. This led to a rapid increase in comparative reaction rates for chars prepared above this temperature.

Waste paper, sewage sludge and MSW were studied for gasification reactivity with $\mathrm{CO} 2$ up to $950^{\circ} \mathrm{C}$, with the bulk of the reaction occurring above $800^{\circ} \mathrm{C}[74,75]$. The paper showed the greatest reactivity due to its large surface area. Acid-washing the biomass resulted in a significant fall in rate, and the temperature peak at $800-950^{\circ} \mathrm{C}$ disappeared. The work was extended [76] by impregnating the biomass with alkali and alkaline earth metals at $10 \%$ by the addition of metal salts. They found the hierarchy of effectiveness of alkali for waste paper as $\mathrm{Li} 2 \mathrm{CO} 3>\mathrm{K} 2 \mathrm{CO} 3>\mathrm{CaCO} 3>\mathrm{Rb} 2 \mathrm{CO} 3$ $>\mathrm{CaSO} 4>\mathrm{Cs} 2 \mathrm{CO} 3>\mathrm{Na} 2 \mathrm{CO} 3$. However, the orders were somewhat reversed with sewage sludge and MSW chars.

Zhang [78] and Zhang et al. [79,80] tested 14 different biomass samples including sawdust, bark and some agricultural wastes by gasifying with $50 \mathrm{kPa}$ steam at $850^{\circ} \mathrm{C}$ chars which had been formed at $900^{\circ} \mathrm{C}$. Some of their reactivity measurements fall into three groups. In Group I are those chars where $[\mathrm{K}]+[\mathrm{Na}]>[\mathrm{Ca}]$, and Group II where $[\mathrm{Ca}]>[\mathrm{K}]+[\mathrm{Na}]$. Group III chars contained very high silica contents (rice husks and bagasse), such that alkali silicates were formed at low temperatures and their catalytic action was curtailed. A random pore model was successfully applied to describe burnout, with the parameters related to potassium content.

Another study by Jiang et al. [81] examined alkali loss from maize stalk, rice husk and cotton stalk during pyrolysis at $900^{\circ} \mathrm{C}$ and subsequent gasification in steam at the same temperature. The results indicate that over half of alkali metals $(\mathrm{K}, \mathrm{Na})$ were released during pyrolysis. In the subsequent char gasification process a further $12-34 \%$ of alkali metal were lost.

\section{Discussion}

Of the metals considered harmful and listed in the Introduction, the least volatile ones, namely $\mathrm{Ni}, \mathrm{Cr}$ and $\mathrm{V}$ are retained in the bottom ash (and cyclone ash where fitted). Those which are more volatile, $\mathrm{As}, \mathrm{Pb}, \mathrm{Cd}$ and $\mathrm{Hg}$ are concentrated into the flyash, especially in the finer particles. With an efficient particulate removal system, the amount escaping directly to the atmosphere appears to be minimal.

The speciation of chromium residues from the combustion of CCA timber was found to be overwhelmingly $\mathrm{Cr}^{\mathrm{III}}$ [50], and a small amount of arsenic present as the trivalent form [49]. There appears to be no information as to whether these figures would be replicated for other biomass.

The role of alkali in biomass is important. The literature results demonstrate that the degree of conversion of the biomass during the combustion or gasification is linked with the catalytic effet of alkalis. As alkali compounds have high vapour pressures, they tend to evaporate during extended use at gasifier and combustion temperatures.

When considering the ultimate disposal of the residuals from thermal processing, their final repository will be the earth. An ash is suitable for spreading on soil if the emission regulations are met, but alternatively if it is highly contaminated it will require interment in a secure landfill. Since all the metals apart from mercury and to a lesser extent Se and As are effectively retained in the ash, the concentration in the ash will be determined by the concentration of metals and ash-forming minerals in the feed.

A number of legislative limits applying to heavy metals for application to soil are presented in Table 5, relating to sewage sludge and general waste materials. Some of the ashes described in this review were suitable for dispersion into soil, but there are some difficult materials. The most likely to meet regulations are carefully-selected demolition timber and phytoremediation plants, whereas undifferentiated demolition materials are high in lead, chromium and arsenic. Since ash from wood-firing is regarded as unsuitable for soil remediation due to its cadmium content, the situation will be much worse with sewage sludge and some paper sludges. 
Table 5

Some limits for heavy metal concentrations in ash for application to soil $\left(\mathrm{mg} \mathrm{kg}^{-1}\right)$.

\begin{tabular}{|c|c|c|c|c|c|}
\hline Metal & $\begin{array}{l}\text { Sludge Austria } \\
\text { [11] }\end{array}$ & $\begin{array}{l}\text { Waste Swiss } \\
{[40]}\end{array}$ & Forest Austria [23] & $\begin{array}{l}\text { Soil Sth Africa } \\
\text { [8] }\end{array}$ & Sludge EU [9] \\
\hline $\mathrm{Cu}$ & 500 & 500 & 250 & 63 & $50-140$ \\
\hline $\mathrm{Zn}$ & 2000 & 1000 & 1500 & - & $150-300$ \\
\hline Co & 100 & 500 & - & - & - \\
\hline As & 20 & - & - & 12 & \\
\hline $\mathrm{Ni}$ & 100 & 500 & 100 & 32 & $30-75$ \\
\hline $\mathrm{Cr}$ & 500 & 10 & 250 & 64 & - \\
\hline $\mathrm{Pb}$ & 500 & 2 & 100 & 60 & $50-300$ \\
\hline $\mathrm{Cd}$ & 10 & & 8 & - & $1-3$ \\
\hline $\mathrm{Hg}$ & & & - & 0.5 & $1-1.5$ \\
\hline
\end{tabular}

\section{Conclusions}

Despite the range of materials and the various thermal processing conditions considered, the behaviour of the heavy metals and alkali is similar in the following ways.

1. Effectively all heavy metals except mercury are retained in the ash.

2. At low temperature $\left(<1000^{\circ} \mathrm{C}\right)$ the metals are uniformly distributed throughout each ash particle. At higher temperatures, there is loss from the outer layers.

3. The various metals partition between the bottom ash and the flyash in accordance with their inherent volatilities.

4. The more volatile metals tend to be concentrated into the fines (fume), due to vaporisation and recondensation. The fume is present as sub-micron particles.

5. The degree of conversion of the biomass during the combustion or gasification is linked with the catalytic effet of alkali

More research is warranted to confirm the interactions of alkalis with silicate or other mineral species and investigate the compositions allowing catalytic enhancement of combustion or gasification reactions.

\section{References}

[1] OHSA: osha.gov/SLTC/metalsheavy/index.html.

[2] I. Obernberger, T. Brunner, G. Bärnthaler, Chemical properties of solid biofuelssignificance and impact, Biomass Bioenergy 30 (2006) 973-982.

[3] V.Scholz, R. Ellerbrock, The growth productivity, and environmental impact of the cultivation of energy crops on sandy soil in Germany, Biomass Bioenergy 23 (2002) 81-92.

[4] L. Reijnders, Conditions for the sustainability of biomass based fuel use, Energy Policy 34 (2006) 863-876.

[5] A.J. Pedersen, Characterization and electrodialytic treatment of wood combustion fly ash for the removal of cadmium, Biomass Bioenergy 25 (2003) 447-458.

[6] A. Demirbas, Influence of Gas and Detrimental Metal Emissions from Biomass Firing and Co-Firing on Environmental Impact, Energy Sources 27 (2005) 1419-1428.

[7] J. Krook, A. Mårtensson, M. Eklund, Metal contamination in recovered waste wood used as energy source in Sweden, Resour. Conserv. Recy 41 (2004) 1-14.

[8] J.J. Mellem, H. Baijnath, B. Odhav, Translocation and accumulation of $\mathrm{Cr}, \mathrm{Hg}$, $\mathrm{As}, \mathrm{Pb}, \mathrm{Cu}$ and $\mathrm{Ni}$ by Amaranthus dubius (Amaranthaceae) from contaminated sites, J. Environ. Sci. Heal. Part A 44 (2009) 568-575.

[9] J. Werther, T. Ogada, Sewage sludge combustion, Prog. Energy Combust. Sci. 25 (1999) 55-116.

[10] R. Świetlik, M. Trojanowska, M.A. Jóźwiak, Evaluation of the distribution of heavy metals and their chemical forms in ESP-fractions of fly ash Fuel Proc, Technol. 95 (2012) 109-118.

[11] M. Narodoslawsky, I. Obernberger, From waste to raw material-the route from biomass to wood ash for cadmium and other heavy metals, J. Hazard. Mater. 50 (1996) 157-168.

[12] O. Dahl, H. Nurmesniemi, R. Pöykiö, G. Watkins, Comparison of the characteristics of bottom ash and fly ash from a medium-size (32 MW) municipal district heating plant incinerating forest residues and peat in a fluidized-bed boiler, Fuel Process. Technol. 90 (2009) 871-878.

[13] C-S. Yuan, H-Y. Lin, C-H. Wu, M-H. Liu, Partition and size distribution of heavy metals in the flue gas from municipal solid waste incinerators in Taiwan, Chemosphere 59 (1) (2005) 135-145.

[14] M.P. Pavageau, A. Morin, F. Seby, C. Guimon, E. Krupp, C. Pécheyron, J. Poulleau, O.F.X. Donard, Partitioning of metal species during an enriched fuel combustion experiment. Speciation in the gaseous and particulate phases, Environ. Sci. Technol. 38 (2004) 2252-2263.

[15] T. Lind, J. Hokkinen, J.K. Jokiniemi, S. Saarikoski, R. Hillamo, Electrostatic precipitator collection efficiency and trace element emissions from co-combustion of biomass and recovered fuel in fluidized bed combustion, Environ. Sci. Technol. 37 (2003) 2842-2846.

[16] J. Latva-Somppi, M. Moisio, E.I. Kauppinen, T. Valmari, P. Ahonen, U. Tapper, J. Keskinen, Ash formation during fluidized-bed incineration of paper mill waste sludge, J.Aerosol Sci. 29 (1998) 461-480.

[17] M. Strand, J. Pagels, A. Szpila, A. Gudmundsson, E. Swietlicki, M. Bohgard, E. Sanati, Fly ash penetration through electrostatic precipitator and flue gas condenser in a 6 MW biomass fired boiler, Energy Fuels 16 (2002) 1499-1506.

[18] P. Kouvo, R. Backman, Estimation of trace element release and accumulation in the sand bed during bubbling fluidized bed co-combustion of biomass, peat and refuse-derived fuels, Fuel 82 (2003) 741-753.

[19] J. Corella, J.M. Toledo, Incineration of doped sludges in fluidized bed. Fate and partitioning of six targeted heavy metals. I. Pilot plant used and results, J. Hazard. Mater. 80 (2000) 81-105.

[20] J.M. Toledo, J. Corella, L.M. Corella, The partitioning of heavy metals in incineration of sludges and waste in a bubbling fluidised bed 2. Interpretation of results with a conceptual model, J. Hazard. Mater. B126 (2005) 158-168.

[21] J.H. Zeuthen, P.A. Jensen, J.P. Jensen, H. Livbjerg, Aerosol Formation during the Combustion of Straw with Addition of Sorbents, Energy Fuels 21 (2) (2007) 699-709.

[22] S. Abanades, G. Flamant, B. Gagnepain, D. Gauthier, Fate of heavy metals during municipal solid waste incineration, Waste Manage. Res. 20 (2002) 55-68.

[23] I. Obernberger, F. Biedermann, W. Widmann, R. Riedl, Concentrations of inorganic elements in biomass fuels and recovery in different ash fractions, Biomass Bioenergy 12 (1997) 211-224.

[24] T. Valmari, E.I. Kauppinen, J. Kurkela, J.K. Jokiniemi, G. Sfiris, H. Revitzer, Fly ash formation and deposition during fluidized bed combustion of willow, Aerosol Sci 29 (1998) 445-459.

[25] S. Jiménez, J. Ballester, A comparative study of different methods for the sampling of high temperature combustion aerosols, Aerosol Sci. Technol. 39 (9) (2005) 811-821.

[26] A. Ljung, A. Nordin, Theoretical Feasibility for Ecological Biomass Ash Recirculation: Chemical Equilibrium Behavior of Nutrient Elements and Heavy Metals during Combustion, Environ. Sci. Technol. 31 (1997) 2499-2503.

[27] L. Li, C. Yu, J. Bai, Q. Wang, Z. Luo, Heavy metal characterization of circulating fluidized bed derived biomass ash, J. Hazard. Mater. 233-234 (2012) 41-47.

[28] H. Pan, T.L. Eberhardt, Characterisation of flyash the the gasification of wood and assessment for its application as a soil amendment, BioResources 6 (2011) 3987-4004.

[29] A.T. Lima, L.M. Ottosen, A.J. Pedersen, A.B. Ribeiro, Characterisation of flyash from bio and municipal ash, Biomass Bioenergy 32 (2008) 277-282.

[30] I.H. Hwang, T. Matsuto, N. Tanaka, Y. Sasaki, K. Tanaami, Characterization of char derived from various types of solid wastes from the standpoint of fuel recovery and pretreatment before landfilling, Waste Manage. 27 (2007) $1155-1166$

[31] T. Grasso, R.S. Atkins, The composition of recycled wood fuel: environmental permitting implications, 16th IGT Conference, Energy from Biomass Wastes Washington DC (1991) 73-94.

[32] B.R. Stanmore, Report to Visy Ltd (2001).

[33] A.A. Khan, W. De Jong, P.J. Jansens, H. Spliethoff, Biomass combustion in fluidized bed boilers: Potential problems and remedies, Fuel Process. Technol. 90 (1) (2009) 21-50

[34] M.C. Freeman, W.J. O'Dowd, T.D. Brown, R.A. Hargis Jr., R.A. James, S.I. Plasynski, G.F. Walbert, A.F. Lowe, J.J. Battista Jr., Pilot-scale air toxics R\&D assessment of creosote-treated and PCP-treated wood cofiring for pulverized coal utility boiler applications, Biomass Bioenergy 19 (2000) 447-456.

[35] R. Nagendran, A. Selvam, K. Joseph, C. Chiemchaisri, Phytoremediation and rehabilitation of municipal solid waste landfills and dumpsites, Waste Manage. 26 (2006) 1357-1369.

[36] Q.-R. Wang, X.-M. Liu, Y.-S. Cui, Y.-T. Dong, P. Christie, Responses of legume and non-legume crop species to heavy metal in soils with multiple metal contamination, J. Environ. Health, Part A 37 (2002) 611-621.

[37] P.B.A. Nanda Kumar, V. Dushenkov, H. Motto, I. Raskin, Phytoextraction, The use of plants to remove heavy metals from soils, Environ. Sci. Technol. 29 (1995) $1232-1238$ 
[38] A. Sas-Nowosielka, R. Kucharski, E. Malkowski, M. Pogrzeba, J.M. Kuperberg, K. Kryňski, Phytoextraction crop disposal-an unsolved problem, Environ. Pollut. 37 (2004) 3-37, 9.

[39] M. Stals, E. Thijssen, J. Vangronsveld, R. Carleer, S. Schreurs, J. Yperman, Flash pyrolysis of heavy metal contaminated biomass from phytoremediation: Influence of temperature, entrained flow and wood/leaves blended pyrolysis on the behaviour of heavy metals, J, Anal. Appl. Pyrol 87 (2010) 1-7.

[40] C. Keller, C. Ludwig, F. Davoli, J. Wochele, Thermal treatment of-metal-enriched biomass produced from heavy metal phytoextraction, Environ. Sci. Technol. 39 (2010) 3359-3367.

[41] P. Vervaeke, F.M.G. Tack, F. Navez, J. Martin, M.G. Verloo, N. Lust, Fate of heavy metals during fixed bed downdraft gasification of willow wood harvested from contaminated sites, Biomass Bioenergy 30 (2006) 58-65.

[42] A.K. Gupta, S. Sinha, Phytoextraction capacity of the plants growing on tannery sludge dumping sites, Bioresour. Technol. 98 (2007) 1788-1794.

[43] X-L. Yan, T-B. Chen, X-Y. Liao, Z-C. Huang, J-R. Pan, T-D. Hu, C-J. Nie, H. Xie, Arsenic transformation and volatilization during incineration of the hyperaccumulator Pteris vittata L., Environ. Sci. Technol. 42 (2008) 1479-1484.

[44] S. Willscher, D. Mirgorodsky, L. Jablonski, D. Ollivier, D. Merten, G. Büchel, J. Wittig, P. Werner, Field scale phytoremediation experiments on a heavy metal and uranium contaminated site, and further utilization of the plant residues, Hydrometallurgy 131- 132 (2013) 46-53.

[45] L. Helsen, E. Van den Bulck, Review of disposal technologies for chromated copper arsenate (CCA) treated wood waste, with detailed analysis of thermochemical conversion processes, Environ, Pollut 124 (2005) 301-314.

[46] J. Jambeck, K. Weitz, H. Solo-Gabriele, T. Townsend, S. Thorneloe, CCA-Treated wood disposed in landfills and life-cycle trade-offs with waste-to-energy and MSW landfill disposal, Waste Manage. 27 (2007) S21-S28.

[47] K. Lundholm, J.M. Rogers, B.S. Haynes, D. Boström, A. Nordin, Fate of Cu, Cr, and As during the combustion stages of CCA-treated wood fuel particles, Energy Fuels 22 (2008) 1589-1597.

[48] J.M. Rogers, M., Stewart, J.G., Petrie, B.S. Haynes, Deportment and management of metals produced during combustion of CCA-treated timbers, 1st Int WasteEng Conference, Albi, France, May 17-19 (2005) Paper C49.

[49] S.J. Wasson, W.P. Linak, B.K. Gullett, C.J. King, A. Touati, F.E. Huggins, Y. Chen, N. Shah, G.P. Huffman, Emissions of chromium, copper, arsenic and PCDD/Fs from open burning of CCA-treated wood, Environ, Sci. Technol. 39(2005) 8865-8876.

[50] J. Song, B. Dubey, Y.-C. Jang, T. Townsend, H. Solo-Gabriele, Implication of chromium speciation on disposal of discarded CCA-treated wood, J. Hazard. Mater. B128 (2006) 280-288.

[51] L.M. Ottosen, A.J. Pedersen, I.V. Christensen, Characterisation of residues from thermal treatment of treated wood and extraction of $\mathrm{Cu}, \mathrm{Cr}$, As and $\mathrm{Zn}$, Wood Sci, Technol 39 (2005) 87-99.

[52] Cui, Y. Ninomiya, M. Masui, H. Mizukoshi, T. Sakano, C. Kanaoka, Fundamenta behaviours in combustion of raw sewage sludge, Energy Fuels 20 (2006) 77-83.

[53] M. Van de Velden, R. Dewil, J. Baeyens, L. Josson, P. Lanssens, The distribution of heavy metals during fluidised bed combustion of sludge (FBSC), J. Hazard. Mater. 151 (2008) 96-102.

[54] J. Han, M. Xu, H. Yao, M. Furuuchi, T. Sakano, P. Kanchanapiya, C. Kanaoka, Partition of heavy metal and alkali metals during sewage sludge incineration, Energy Fuels 20 (2006) 583-590.

[55] A.-L.Elled, L.-E. Åmand, B. Leckner, B.-Å. Andersson, The fate of trace elements in fluidised bed combustion of sewage sludge and wood, Fuel 86 (2007) 843-852.

[56] J. Shao, R. Yan, H. Chen, H. Yang, D.H. Lee, D.T. Liang, Emission characteristics of heavy metals and organic pollutants from the combustion of sewage sludge in a fluidized bed combustor, Energy Fuels 22 (2008) 2278-2283.

[57] D. Luts, K. Devoldere, B. Laethem, W. Bartholomeeusen, P. Ockier, Coincineration of dried sewage sludge in coal-fired power plants: a case study, Water Sci. Technol. 42 (2000) 259-268.

[58] H. Spliethoff, W. Scheurer, K.R.G. Hein, Effect of co-combustion of sewage sludge and biomass on emissions and heavy metal behaviour, Trans IChemE Part B 78 (2000) 33-39.
[59] J. Oral, J. Sikula, R. Puchyr, Z. Hajny, P. Stehlik, L. Bebar, Processing of waste from pulp and paper plant, J.Clean Prod. 13 (2005) 509-515.

[60] J.A. Koziński, G. Zheng, V. Uloth, P. Gangli, W. Hutny, Analysis of hydrocarbons and ash particles formed from contaminated industrial biowaste under combustion-like conditions, Environ. Sci. Technol. 33 (1999) 4318-4325.

[61] G. Zheng, J.A. Koziňski, Thermal events occurring during the combustion of biomass residue, Fuel 79 (2000) 181-192.

[62] J. Louhimo, R. Burelle, T. Suoniemi, Operating experiences with a bubbling fluid bed boiler firing paper mill sludges and biomass at united paper mills, Kaipola plant, Finland, Pulp Pap-Canada 96 (1995) 52-56.

[63] K.K. Rink, J.A. Kozinski, J.S. Lighty, Biosludge incineration in FBCs: Behaviour of ash particles, Combust. Flame 100 (1995) 121-130.

[64] F. Eldabbagh, A. Ramesh, J. Hawari, W. Hutny, J.A. Kozinski, Particle-metal interactions during combustion of pulp and paper biomass in a fluidized bed combustor, Combust. Flame 142 (2005) 249-257.

[65] N.S. Bolan, A.A. Szogi, T. Chuasavathi, B. Seshadri, M.J. Rothrock Jr., P. Panneerselvam, Uses and management of poultry litter, Worlds Poult. Sci. J. 66 (2010) 673-698.

[66] N. Whitely, R. Ozao, R. Artiaga, Y. Cao, W.P. Pan, Multi-utilization of chicken litter as biomass source. Part I. Combustion, Energy Fuels 20 (6) (2006) 2660-2665.

[67] P. Abelha, I. Gulyurtlu, D. Boavida, J. Seabra Barros, I. Cabrita, J. Leahy, B. Kelleher M. Leahy, Combustion of poultry litter in a fluidised bed combustor, Fuel 82 (2003) 687-692.

[68] L. Jia, E.J. Anthony, Combustion of poultry-derived fuel in a CFBC, in: Proceedings of the 20th International Conference on Fluidized Bed Combustion, Part 2, 2010, pp. 271-276.

[69] J. Lundgren, E. Petersson, Combustion of horse manure for heat production, Bioresour. Technol. 100 (2009) 3121-3126.

[70] WBG www.ifc.org/ifcext/enviro.nsf/AttachmentsByTitle/guialummfgWB/ \$FILE/alumPPAH.p df.

[71] W. Klose, M. Wölki, On the intrinsic rate of biomass char gasification with carbon dioxide and steam, Fuel 84 (2005) 8858-8892.

[72] L. Devi, K.J. Ptasinski, F.J.J.G. Janssen, A review of the primary measures for tar elimination in biomass gasification processes, Biomass Bioenergy 24 (2003) $125-140$.

[73] T.G. Devi, M.P. Kannan, V.P. Abduraheem, Jump in the air gasification rate of potassium-doped cellulosic chars, Fuel Process. Technol. 91 (2010)1826-1831.

[74] D. Vamvuka, E. Karouki, S. Sfakiotaki, Gasification of waste biomass chars by carbon dioxide via thermogravimetry Part I: Effect of mineral matter, Fuel 90 (2011) 1120-1127.

75] K. Mitsuoka, S. Hayashi, H. Amano, K. Kayahara, E. Sasaoaka, M.A. Uddin, Gasification of woody biomass char with $\mathrm{CO}_{2}$ : The catalytic effects of $\mathrm{K}$ and Ca species on char gasification reactivity, Fuel Process. Technol. 92 (2011) 26-31.

[76] D. Vamvuka, E. Karouki, S. Sfakiotaki, P. Salatino, Gasification of Waste Biomass Chars by Carbon Dioxide via Thermogravimetry-Effect of Catalysts, Combust. Sci. Technol. 1 (2012) 64-77.

[77] Y. Huang, X. Yin, C. Wu, C. Wang, J. Xie, Z. Zhou, Effects of metal catalysts on $\mathrm{CO} 2$ gasification reactivity of biomass char, Biotechnol. Adv. 27 (2009) $568-572$.

[78] W. Zhang, Automotive fuels from biomass via gasification, Fuel Process. Technol. 91 (2010) 866-876.

[79] Y. Zhang, M. Ashizawa, S. Kajitani, Calcium loading during the dewatering of wet biomass in kerosene and catalytic activity for subsequent char gasification, Fuel 87 (2008) 3024-3030.

[80] Y.Zhang, M. Ashizawa, S. Kajitani, K. Miura, Proposal of a semi-empirical kinetic model to reconcile with gasification reactivity profiles of biomass chars, Fuel 87 (2008) 475-481.

[81] L. Jiang, S. Hu, S. Xiang, S. Su, L. Sun, K. Xu, Y. Yao, Release characteristics of alkali and alkaline earth metallic species during biomass pyrolysis and steam gasification process, Bioresour. Technol. 116 (2012) 278-284. 